\title{
Lectora Inspire in Learning Congruence Triangles in Higher Education
}

\author{
Ardhi Sanwidi ${ }^{1 *}$, Galuh Tyasing Swastika ${ }^{2}$ \\ ${ }^{1 \& 2}$ Program Studi Matematika, Universitas Nahdlatul Ulama Blitar \\ Jalan Masjid No. 22, Blitar, Indonesia. \\ *E-mail : ardhisanwidhi@unublitar.ac.id, Telp:+6285731292484
}

Article received : 06-08-2018, article revised:03-09-2018, article published: 07-09-2018

DOI : 10.25273/jipm.v7i1.3222

\begin{abstract}
Abstrak
Tujuan dari penelitian ini adalah mengetahui penggunaan pembelajaran berbantuan Lectora Inspire, menganalisis aktivitas mahasiswa dalam proses pembelajaran, dan untuk mengetahui peningkatan prestasi mahasiswa dalam materi kongruensi segitiga. Penelitian ini menggunakan pendekatan Action Research. Penelitian menggunakan dua siklus pembelajaran. Hasil dari penelitian ini adalah penggunaan pembelajaran berbantuan Lectora Inspire dapat meningkatkan aktivitas mahasiswa dalam proses pembelajaran materi kongruensi segitiga. Hal ini dapat dilihat dari persentase aktivitas mahasiswa dari $72,85 \%$ menjadi $81,25 \%$. Selain itu, kegiatan pembelajaran ini dapat meningkatkan prestasi mahasiswa. Hal ini dapat dilihat dari peningkatan ketuntasan persentase hasil belajar mahasiswa dari 53,1\% menjadi 78,1.
\end{abstract}

Kata Kunci: Lectora Inspire, Kongruensi segitiga

\begin{abstract}
The purpose of this study was to determine the use of Lectora Inspire assisted learning, analyze student activities in the learning process, and to find out the improvement of student achievement in triangular congruence material. This study uses an Action Research approach. The study uses two learning cycles. The results of this study are the use of Lectora Inspire assisted learning can increase student activity in the learning process of triangular congruence material. This can be seen from the percentage of student activity from $72.85 \%$ to $81.25 \%$. In addition, this learning activity can improve student achievement. This can be seen from the increase in completeness percentage of student learning outcomes from $53.1 \%$ to $78.1 \%$.
\end{abstract}

Keywords: Lectora Inspire, Triangular congruence 



\section{INTRODUCTION}

NCTM (2000) states that one of the objectives of learning mathematics is to help humans solve problems in everyday life. Problem solving ability can be formed one of them in classroom learning, in which students are required to foster liveliness in the learning process (Wena, 2009; Soedjadi, 1999). Therefore, educators or lecturers are expected to be able to carry out problemsolving based learning strategies which seek student-centered learning (active students).

Formal education in this regard has an important role in the development of the things which had been mentioned above, namely by making quality learning. One of the most influential in the learning is appropriate teaching materials (Dewi \& Harahap, 2016).

Based on observations that researchers have made about the learning process in class and interviews with one of the students who took Geometry courses the previous year at UNU Blitar, it was found that most of the learning process in the classroom only emphasized understanding the concept by way of lecturers transferring knowledge to students without the process of building a concept. Learning can lead to student passivity and the dominant attitude of lecturers. The type of learning that is often applied by lecturers who teach Geometry courses is included in the direct learning syntax.

Given the weaknesses in conventional direct learning, there needs to be an effort to overcome this. Educators who are careful and responsive to learning needs must use appropriate learning models, methods and media in learning, so that they are motivated by learning (Ariani \& Haryanto, 2010). And conventional learning method allowed only few of materials to be absorbed (Priyono,
2018)

Students experience difficulties in understanding learning related to images in this Geometry course. The type of learning that is often applied by lecturers who teach Geometry courses is included in the direct learning syntax. The learning is carried out in a monotonous manner, which is centered on the teacher and places the teacher as a single source (Ardian \& Munadi, 2015). For this reason, researchers will examine Geometry learning in triangular congruence material. One alternative that can make students more active in learning activities and pay attention to a comfortable and pleasant atmosphere is to use learning media (Arsyad, 2011).

Geometry, one of the oldest branches in mathematics, is known as one of the important learning areas in mathematics, involving the concepts of planar and spatial shapes (Fidan \& Türnüklü, 2010). Congruence is defined as the same shape which is not necessarily in the same size. The conceptualization of another kongruence which is more based on mathematics involves the observation of a proportional relation when the relevant lengths in similar shapes or within a shape are compared (Seago, Jacobs, Heck, Nelson \& Malzahn, 2013).

Baykul (2009) said that the shapes that can be overlapped are congruent whereas the shapes with the same forms are similar shapes. According to Baykul (2009), two planar shapes are congruent if their sizes and forms are same, and congruence is a special case of similarity. Uppal, John, Gill and Chawla (2006) reflected that two similar shapes, although they have the same shape, do not need to be in the same size, and all congruent shapes are similar; however, similar shapes may not be congruent. The 
comprehension of the concept of similarity underlies the comprehension of several geometry features. In this study deals with the subject of congruence and similarity in triangles.

Some experts argue (Gagne in Sadiman, 2012; Briggs in Sadiman, 2012) that the media as a physical component or tool that can convey information so that it stimulates students in learning. Learning media as a component of learning that has an important role in learning activities. Media is important in the learning system because without communication media it will not happen well and the learning process as a communication process will not take place optimally. In line with the opinion (Criticos, 1996) the media is one component of communication, namely as a messenger from the communicator to the communicant. The success of the messages received by the communicant in the learning process cannot be separated from the responsibility of the communicator in delivering the message.

Kemp and Dayton (1985) state that the contribution of instructional media in conveying learning messages is more standardized, more attractive, more interactive, learning time can be shortened, the quality of learning can be improved, the learning process can take place indefinitely, students behave and lecturers play a positive role towards learning. One of the media in the form of interactive multimedia, which is equipped with a control device so that users can control the course of the media (Daryanto, 2010). In addition there are audio visual media is one type of learning media that can be used in the delivery of initial information or reinforcement (Supriyadi, 2007).

Multimedia is divided into two categories, namely linear multimedia and interactive multimedia. Linear multimedia is a multimedia that is not equipped with any controller that can be operated by the user. This multimedia runs sequentially, for example: TV and movies. Interactive multimedia is a multimedia that is equipped with a controller that can be operated by the user, so that users can choose what they want for the next process, for example: interactive learning, game applications, etc. (Daryanto, 2016).

One of the media used in learning is Lectora Inspire. Lectora Inspire is an elearning development tool, also known as authoring software, developed by Trivantis Corporation. By using this, lecturers can create interactive media that can be used in classrooms, on-line, or self-study students.

By using lectora inspire media, lecturers can create or combine visual media, audio, audiovisual content and tests in one application, and are relatively easy to apply or apply because they do not require an advanced understanding of programming languages (Mas'ud, 2012). Lectora Inspire also allows users to use various media files to make content more interesting. Therefore, in this article shows the results of the study of the use of Lectora Inspire in learning triangular congruence in geometry lectures.

\section{METHOD}

This type of research is action research in which systematic and planned investigations or studies are carried out by researchers to improve learning in class by making improvements or changes and studying the consequences (Sunardi et al, 2001). The step in this study begins with the introduction and then continues with the implementation of actions consisting of 
planning, implementing, observing, last reflection.

If it is known the location of success or obstacles from the implementation of cycle I, the researcher determines the design for the implementation of cycle II. The results of the second cycle will be used as a guideline to see the improvement in student learning outcomes. If in the second cycle, student learning outcomes are obtained more than student learning outcomes in cycle I, learning is stopped until two cycles. Due to time constraints, this learning will be stopped until cycle II.

The research instrument used is in the form of assignments and tests in each cycle I and II. In addition, researchers compiled Lectora Inspire assisted learning media on triangular congruence material for use in learning. Field notes are used to determine the activities of students and lecturers during learning. In this study data collection methods used are observation, tests and interviews.

Data analysis used in this research is qualitative descriptive analysis. Includes: 1) lecturer and student responses to Lectora Inspire assisted learning through interviews; 2) Student activities during the learning process; 3) Completeness of student learning outcomes after learning takes place; 4) Increasing student learning outcomes in this study is comparing the average student learning outcomes in the first and second cycles. The average student learning outcomes are obtained from the pretest and final test scores. The qualitative data is the response of lecturers and student activities, analyzed using a method that refers to Miles Huberman (Sugiyono, 2009), namely data reduction, data presentation and conclusion drawing. For quantitative data using mathematical attention.
In student activity (Pa) obtained by the formula:

$$
\begin{aligned}
& \mathrm{P}_{\mathrm{a}}=\frac{A}{N} \times 100 \% \\
& \text { Information : } \\
& \mathrm{P}_{\mathrm{a}}: \text { Student activity percentage } \\
& A: \text { Number of scores obtained by } \\
& \text { students } \\
& N: \text { Total score }
\end{aligned}
$$

Tabel 1. Criteria for student activity

\begin{tabular}{cc}
\hline Activity Category & percentage \\
\hline Very good & $\mathrm{Pa} \geq 95 \%$ \\
Good & $80 \% \leq \mathrm{Pa}<95 \%$ \\
Pretty good & $65 \% \leq \mathrm{Pa}<80 \%$ \\
Not good & $50 \% \leq \mathrm{Pa}<65 \%$ \\
Less & $\mathrm{Pa}<50 \%$ \\
\hline
\end{tabular}

For completeness of student learning outcomes, using formulas:

$$
\begin{gathered}
P=\frac{F}{N} \times 100 \% \\
\text { Information: }
\end{gathered}
$$

$\mathrm{F}=$ The number of students who get a score of $\geq 75$

$\mathrm{N}=$ Number of students (maximum who take the test)

$\mathrm{P}=$ percentage of students completed (Modification Djamarah, 2010).

\section{RESULT}

The research was conducted on students of Geometry Class S1 Mathematics of Nahdlatul Ulama University, Blitar. Data collection begins with observations and interviews. Observation activities were carried out to find out student learning activities in class, how to teach lecturers, and class conditions. Interview with the Geometry lecturer to find out more clearly the learning that is applied, as well as to know the description of the ability of students in participating in Geometry learning.

The results of the observation analysis of student learning activities in the 
first cycle at the first meeting are: paying attention to the lecturer explanation $84.4 \%$; eager to receive learning $79.2 \%$; workout $63.5 \%$; solve $76 \%$ problem; collaboration in group discussions $71.9 \%$; present the work results $54.2 \%$; issue $61.5 \%$ opinion; and record and summarize $77.1 \%$.

Student activity at meeting II was obtained results: in paying attention to the lecturer explanation $83.3 \%$; eager to receive learning $80.2 \%$; exercise $70.8 \%$; solve $76 \%$ problem; collaboration in group discussions $71.9 \%$; present the results of the work $66.7 \%$; issued an opinion of $70.8 \%$; and recorded and concluded $78.1 \%$. Based on these data, student activity in the first cycle was $72.88 \%$.

The application of Lectora Inspire assisted learning through assignments in cycle 1 is still incomplete. The completeness of the student test scores is $62.5 \%$, which is $56.3 \%$, the second meeting is $68.8 \%$, and the student learning outcomes at the end of the cycle are $53.1 \%$. The classical absorption of students has not yet been completed because it has not reached mencapai $75 \%$ of the total number of students.

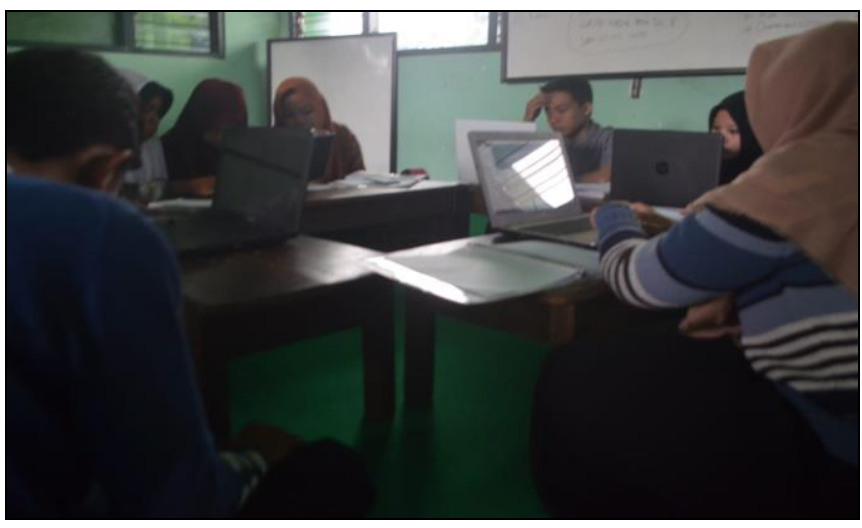

Figure 1. Learning activities with Lectora Inspire

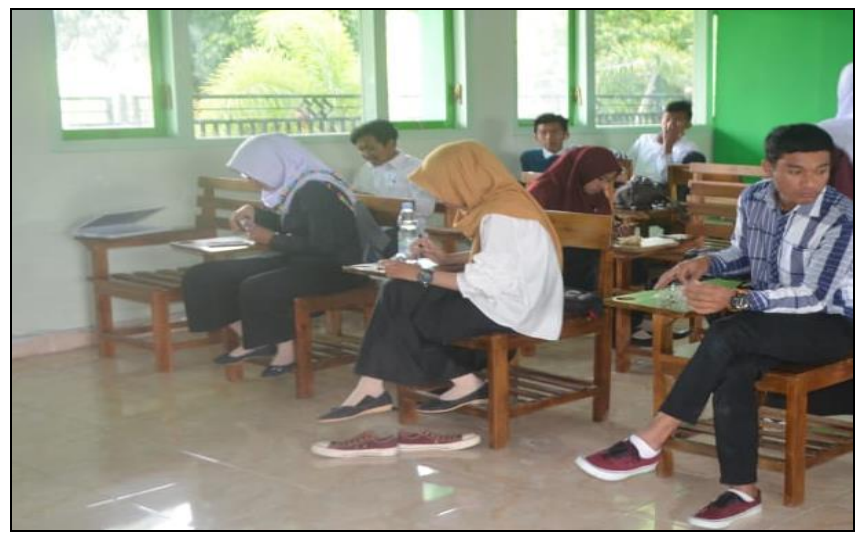

Figure 2. Students make preparation for learning outcomes

The results of the observation analysis of student learning activities in cycle II at meeting I were: paying attention to the lecturer explanation $84.4 \%$; eager to receive $85.4 \%$ learning; workout $72.9 \%$; solve
$71.9 \%$ problem; cooperation in group discussions $80.2 \%$; present work results $67.7 \%$; issue $71.9 \%$ opinion; and recorded a conclusion of $80.2 \%$. 


\section{JIPM (Jurnal Ilmiah Pendidikan Matematika), 7(1), September 2018- 71}

Ardhi Sanwidi, Galuh Tyasing Swastika

The results of observing student activities at meeting II were: paying attention to the lecturer explanation $94.8 \%$; eager to receive lessons $94.8 \%$; $80.2 \%$ exercise; solve problems $81.3 \%$; active in groups of $85.4 \%$; present the work results $78.1 \%$; issue $84.4 \%$; and recorded a conclusion of $86.5 \%$. Based on these data obtained student activity in the second cycle was $81.25 \%$.

The application of Lectora Inspire assisted learning through assignment has been completed. The completeness of the value of student assignments classically is $73.45 \%$, that is at the first meeting of $71.9 \%$, the second meeting is $75 \%$, and the student learning outcomes in the final cycle test are $78.1 \%$. The classical absorption of students has been completed because it has reached $\geq$ $75 \%$ of the total number of students, namely 25 students. Based on these data, there were students who had not yet completed their study, namely at the third meeting there were 4 students, the IV meeting had 2 students, and the final cycle test had 1 student.

\section{DISCUSSION}

From the description, it is known that the results of the cycle II test have achieved the completeness of the learning result in a klaksikal way that is $78.10 \%$. Thus Lectora Inspire assisted learning can improve student learning outcomes, making students tend to be more active and easy to understand triangle congruence.

After carrying out the learning in cycles I and II, an evaluation was obtained that the learning targets to be achieved, which included: 1) students were enthusiastic and enthusiastic in participating in teaching and learning activities; 2) students are more active in working on questions; 3) students are more active in group learning, and 4) there is an increase in learning outcomes in accordance with the initial objectives of the study, namely the application of Lectora Inspire assisted learning. Based on these considerations, the learning cycle carried out in this study was ended.

Some of the findings during the use of Lectora Inspire assisted learning were that while using Lectora Inspire assisted learning in the material of triangular congruence students looked more enthusiastic, happy, excited, and active. This is because the lecturer gives the opportunity to ask questions and issue opinions. In addition, in working on test questions, students still make a lot of mistakes. Among the mistakes made are in the elaboration of the theorems that will be used in the completion of test questions. Geometry based computer instruction had a significant effect on students' achievement in geometry compared to traditional instruction (Turk \& Akyuz, 2016)

Based on the results of the study, the percentage of student activity and completeness of learning showed an association. This can be seen in students whose percentage of activity is high, but the percentage of learning completeness is also high. From the overall results of this study indicate that Lectora Inspire assisted learning can prove to be an alternative in geometry learning.

\section{CONCLUSION}

After the research process is carried out until the results are obtained, it can be concluded that the Lectora Inspire assisted learning model on triangular congruence material runs smoothly and is proven to increase student activity and their learning outcomes. This can be seen from the increase in percentage of student learning outcomes $53.1 \%$ to $78.1 \%$. 
The suggestions that can be raised in connection with this study in the future, namely the application of Lectora Inspire assisted learning can be done on Geometry

\section{REFERENCES}

Ardian, A., \& Munadi,S. (2015). Pengearuh strategi pembelajaran Student-centered Learning dan Kemampuan Spasial. Jurnal Pendidikan Teknologi Dan Kejuruan, 22,(4), 454-466.

Ariani, N., \& Haryanto, D. (2010). Pembelajaran Multimedia di Sekolah Pedoman Pembelajaran Inspiratif, Konstruktif, dan Prospektif. Jakarta: Prestasi Pustaka.

Arsyad, Azhar. (2007). Media Pembelajaran. Jakarta. PT Grafindo Persada.

Baykul, Y. (2009). İlköğretimde matematik ögretimi. Ankara: Pegem

Criticos, C. (1996). Media selection. Plomp, T., \& Ely, D. P. (Eds.): International Encyclopedia of Educational Technology, 2nd edition. New York: Elsevier Science, Inc

Daryanto. (2012). Media pembelajaran. Bandung:PT. sarana Tutorial Nurani Sejahtera.

Daryanto. (2016). Media Pembelajaran Peranannya Sangat Penting dalam Mencapai Tujuan Pembelajaran. (Edisi ke 2 Revisi). Yogyakarta: Gava Media.

Dewi, I., \& Harahap, M., S. (2016). The Development of Geometri Teaching Materials Based on Constructivism to Improve the Students' Mathematic Reasoning Ability through Cooperative Learing Jigsaw at the Class VIII of SMP Negeri 3 Padangsidimpuan. Journal of learning with other subjects, so that students are more relaxed when receiving learning..

Education and Practice, Vol.7, No.29.

Djamarah, Syaiful Bahri. (2010). Strategi Belajar Mengajar. Jakarta: PT Rineka Cipta.

Fidan, Y., \& Türnüklü, E. (2010). Examination of 5th grade students, levels of geometric thinking in terms of some variables. Pamukkale University Journal of Education, 27, 185-197

Kemp, J. E. \& Dayton, D. K.. (1985). Planning and producing instructional media. New York: Harper and Row Publisher

Mas'ud, Muhammad. (2012). Membuat Multimedia Pembelajaran dengan Lectora. Yogyakarta: Pustaka Shonif NCTM. (2000). Principles and Standards for School Mathematics.

Priyono. (2018). The Implementation of PAIKEM (Active, Innovative, Creative, Effective, and Exiting Learning) and Conventional Learning Method to Improve Student Learning Results. Journal of Social Studies Education Research, vol. 2, p.124-137.

Sadiman. A.S. dkk. (2012). Media pendidikan. Jakarta:Raja Grafindo Persada.

Seago, N.M., Jacobs, J.K., Heck, D.J., Nelson, C.L., \&Malzahn, K.A. (2013). Impacting teachers' understanding of geometric similarity: results from field testing of the 
Learning and Teaching Geometry professional development materials.

Professional Development in

Education, 40(4), 627-653.

Soedjadi, R. (1999). Kiat Pendidikan Matematika Di Indonesia. Jakarta: Dirjen Dikti Depdiknas.

Sugiyono. (2009). Metode Penelitian Kuantitatif Kualitatif dan RnD. Bandug:

Alfabeta.

Sunardi, dkk. (2001). Konsep Dasar Penelitian Tindakan kelas. Makalah disajikan dalam Workshop Penelitian Tindakan Kelas (PTK). SLTP N 3 Jember, Jember, 23-25 Oktober 2001
Supriyadi. (2007). Jembatan. Yogyakarta: Beta Offset.

Turk, H., S., and Akyuz, D., (2016). The Effects of Using Dynamic Geometry on Eighth Grade Students, Achievement and Attitude towards Triangles. International Journal for Technology in Mathematics Education, v23 n3 p95-102.

Uppal, S., John, M., Gill, J., \& Chawla, A. (2006). Triangles. Reston, VA: National Council of Teachers of Mathematics

Wena, M. (2009). Strategi Pembelajaran Inovatif Kontemporer Suatu Tinjauan Konseptual Operasional. Jakarta: Bumi Aksara 